\title{
Carcinomatous Meningitis: The Natural History of Successfully Treated Metastatic Bladder Cancer
}

\author{
S. Tadepallia T. Coleman ${ }^{a} \quad$ L.A. Hacket ${ }^{a} \quad$ G.B. Liles ${ }^{b}$ \\ a Department of Hematology and Oncology and ${ }^{b}$ Department of Pathology, \\ Georgia Health Sciences University, Augusta, Ga., USA
}

\section{Key Words}

Carcinomatous meningitis - Central nervous system · Complete response - Intrathecal methotrexate $\cdot$ Methotrexate, vinblastine, Adriamycin, and cisplatin combination treatment $\cdot$ Transitional cell carcinoma

\begin{abstract}
Carcinomatous meningitis due to bladder cancer is a rare entity reported only in case reports. Optimal therapy is thus poorly defined with earlier cases reporting an unsuccessful outcome. Here we report a case of late carcinomatous meningitis secondary to transitional cell carcinoma (TCC) of the bladder occurring in a patient in complete remission. He was successfully treated with intrathecal methotrexate and whole brain irradiation and experienced prolonged survival after treatment. With modern chemotherapy increasing complete remissions and survival rates in patients with TCC, more and more patients are being reported with carcinomatous meningitis. We raise the question of whether central nervous system prophylaxis should be considered in patients with TCC achieving a complete remission to chemotherapy in the metastatic setting.
\end{abstract}

\section{Introduction}

Carcinomatous meningitis due to bladder cancer is a rare entity reported only in case reports. Optimal therapy is thus poorly defined, with most cases reporting an unsuccessful outcome. Here, we report a case of carcinomatous meningitis secondary to transitional cell carcinoma (TCC) of the bladder successfully treated with intrathecal methotrexate (MTX) and whole brain irradiation. 


\section{Case Report}

A 47-year-old white male presented with TCC of the bladder which had metastasized to bone as revealed by PET-CT. Chemotherapy with cisplatin and gemcitabine resulted in a radiographic complete remission after 7 cycles. Three months after completing chemotherapy, the patient presented with headache. A brain MRI suggested carcinomatous meningitis (see fig. 1, fig. 2). He then developed a right CN III palsy. A lumbar puncture confirmed the diagnosis (see fig. 3). The patient was treated with biweekly intrathecal MTX via an Ommaya reservoir for 6 weeks, resulting in the clearance of his cerebrospinal fluid; however, his cranial nerve palsy persisted. He then underwent whole brain irradiation (3,960 cGy at $180 \mathrm{cGy}$ per day over 22 days by the 'German Helmet' technique) with resolution of his cranial nerve palsy. He is currently alive 9 months after his diagnosis of carcinomatous meningitis.

\section{Discussion}

Cancer of the urinary bladder is diagnosed in approximately 70,500 people each year in the United States, and about 14,000 individuals die [1]. Central nervous system (CNS) involvement is rarely reported. In a study by Anderson et al. [2] involving CNS complications occurring in bladder cancer, no patient developed carcinomatous meningitis and only $1 \%$ of patients developed brain metastasis in a series of 359 patients.

For carcinomatous meningitis associated with other solid tumors, a typical induction regimen consists of a fixed dose of 10 or $12 \mathrm{mg}$ of intrathecal MTX twice weekly for 4 weeks. If clinical response occurs, the frequency of administration is decreased to once weekly for 4-8 weeks; a maintenance regimen is then continued with drug administration every 2 weeks for several months, and then monthly for 2-4 months. The optimal duration of therapy is unknown [3].

The route of delivery of intrathecal chemotherapy may impact outcome. Shapiro et al. [4] demonstrated that MTX administration using an Ommaya reservoir more reliably produced adequate cerebrospinal fluid distribution than administration by lumbar puncture. In another study, 100 patients with clinically and cytologically or radiographically documented neoplastic meningitis stemming from solid tumors received intracerebrospinal fluid liposomal cytarabine or MTX. Progression-free survival (the primary study endpoint) was identical between the sustained-release cytarabine and MTX treatment arms for all 100 patients ( 35 vs. 37.5 days, respectively, $\mathrm{p}=0.79$ ). When progression-free survival was examined as a function of the route of chemotherapy administration (lumbar vs. ventricular), there was no difference for patients treated with sustained-release cytarabine ( 29 vs. 43 days, respectively, $\mathrm{p}=0.35$ ). For patients treated with MTX, however, there was a statistically significant difference favoring patients receiving intraventricular therapy ( 19 vs. 43 days, respectively, $p=0.048$ ) [5]. Hitchins et al. [6] also noted that responses were more frequent if therapy was administered via an Ommaya reservoir. We speculate that placing an Ommaya reservoir in our patient may have contributed to his relatively prolonged overall survival.

There are several cases of transitional cell carcinomatous meningitis reported in the literature - with our case bringing the total to 30 . While some patients presented with grossly widespread disease including the CNS, our literature review suggests that many patients had the complication occur after successful treatment of their systemic disease (see table 1). For example, Bishop et al. [7] reported 2 patients developing disease after systemic treatment with MTX, vinblastine, Adriamycin, and cisplatin (MVAC). 
Matsushita et al. [8] reported a case occurring 16 months after their patient had had a complete response following chemotherapy and surgery, and Boukriche et al. [9] reported a case occurring 4 years after adjuvant treatment for resected bladder cancer. Still, just as many cases present concurrently with widespread systemic disease, suggesting that TCC may have an affinity for the CNS and that carcinomatous meningitis may be more common than realized. The prognosis for most patients with carcinomatous meningitis secondary to TCC is dismal, with patients surviving a median of 38 days [31]. Our review confirms the poor prognosis with an average survival of 2.2 months for all patients in which survival has been reported. Interestingly, the average time to the development of carcinomatous meningitis is 14 months (see table 1 ).

With more cases appearing in the literature, it raises the question: does the successful treatment of systemic disease with modern chemotherapy change the natural history of the disease? Dhote et al. [33] reported on 50 patients with advanced TCC of the bladder treated with MVAC and noted that 8 patients experienced a CNS relapse (16\%). In their series, brain metastasis occurred within a mean of 21 months. In the series by Bishop et al. [6], 2 of 17 patients treated with MVAC had carcinomatous meningitis (12\%). Finally, in a series reported by Sternberg et al. [34], 2 out of 12 patients achieving complete response on MVAC later developed CNS disease (17\%). We can only surmise that in the series by Anderson et al. [2], in which data was collected on patients between 1962 and 2001, the majority of patients did not receive cisplatin-based chemotherapy. With the rising incidence of TCC of the bladder, more and more patients are now dying of complications seen only in advanced stages of disease. With modern chemotherapy, median survival has increased from 3-6 months in the pre-MVAC era to its current figure of almost 1 year. This combination chemotherapy, in a multicenter phase III trial, was shown to increase median survival from 8.2 to 12.5 months [35]. As with any chemotherapy, MVAC is associated with complications like cardiac and renal toxicities, along with neutropenia and mucositis. The rate of death due to MVAC toxicity is around $3-4 \%$ and the diseasefree survival rate is $3.7 \%$ at 6 years $[34,35]$. A newer phase III study has shown the clear advantage of using the gemcitabine-cisplatin combination as it is as effective as MVAC, but with less systemic toxicity [36]. Reports of carcinomatous meningitis occurring when the gemcitabine-cisplatin combination is used are increasing, similar to the trend reported for MVAC. As more and more cases appear in the literature, it may be reasonable to consider CNS prophylaxis in patients who achieve complete remission on chemotherapy in a metastatic setting. 
Table 1. Summary of reported cases on transitional cell carcinoma of bladder and its metastasis to CNS

\begin{tabular}{|c|c|c|c|c|c|c|}
\hline $\begin{array}{l}\text { Study } \\
\text { first author }\end{array}$ & $\begin{array}{l}\text { Stage } \\
\text { at DX }\end{array}$ & Disease course and treatment summary & CR & $\begin{array}{l}\text { Time to } \\
\text { CNS disease } \\
\text { months }\end{array}$ & TX CNS & $\begin{array}{l}\text { OS after } \\
\text { CNS disease } \\
\text { months }\end{array}$ \\
\hline Hust, $1980[10]$ & $\mathrm{nr}$ & cobalt XRT & $\mathrm{nr}$ & 5 & none & 5 \\
\hline Hust, $1980[10]$ & IV & meningitis at presentation & na & 0 & none & 0 \\
\hline Mandell, 1985 [11] & $\mathrm{nr}$ & $\begin{array}{l}\text { radiation and cystectomy at diagnosis, cisplatin } \times 5 \\
\text { at relapse }\end{array}$ & yes & 10 & IT MTX/XRT & $\mathrm{nr}$ \\
\hline Bishop, 1990 [7] & III & MVAC $\times 4$, meningitis after cycle 4 & no & 32 & IT MTX/XRT & 5 \\
\hline Bishop, $1990[7]$ & T4 & cystectomy, MVAC $\times 3$, meningitis after cycle 3 & no & - & none & 4 \\
\hline Hussien, 1989 [12] & IV & $\begin{array}{l}\text { MVAC } \times 5, \text { PR, progressed in } 3 \text { months, phase I } \\
\text { piritrexim with PR }\end{array}$ & no & 9 & IT MTX/XRT & 5 \\
\hline Raghavan, 1991 [13] & $\mathrm{nr}$ & $\begin{array}{l}\text { cisplatin and radiation for localized disease relapsed in } \\
16 \text { months, MVAC } \times 2 \text {, IT therapy and } \\
\text { MVAC } \times 4\end{array}$ & yes & 16 & IT MTX-O & 4 \\
\hline Eng, 1993 [14] & IV & MVAC $\times 5$, pelvic XRT, PR & no & 9 & none & 0 \\
\hline Eng, 1993 [14] & IV & cisplatin and MTX with CR, relapsed 2 years later & yes & 24 & IT MTX/XRT & 3 \\
\hline Steg, 1993 [15] & $\mathrm{nr}$ & $\mathrm{nr}$ & nr & $\mathrm{nr}$ & none & 1 \\
\hline Sugimori, 2005 [16] & IV & presented with meningitis, died of cardiac disease & na & 0 & none & 3 \\
\hline Imamura, 1997 [17] & IV & presented with meningitis & na & 0 & none & 3 \\
\hline Bloch, $1987[18]$ & IV & $\begin{array}{l}\text { surgery for presumed localized disease, brain } \\
\text { metastasis } 2 \text { weeks after surgery, whole body XRT, } \\
\text { meningitis } 3 \text { months later }\end{array}$ & na & 3 & - & 5 \\
\hline Hasbini, 1997 [19] & T3N2 & $\begin{array}{l}\text { surgery, MVAC } \times 4 \text { with CR, meningitis } \\
1 \text { month later }\end{array}$ & yes & 7 & - & 1 \\
\hline Santarossa, 1997 [20] & T4N3 & MVAC $\times 6$, presented 8 months later with meningitis & yes & 14 & IT MTX/XRT & 9 \\
\hline Loizaga, 1998 [21] & I & $\begin{array}{l}\text { BCG vaccine, mitomycin B, then developed } \\
\text { meningitis }\end{array}$ & na & 15 & CMV & 0 \\
\hline Cozzarini, 1999 [22] & III & $\begin{array}{l}\text { MVAC } \times 2 \text { with no improvement, surgery, } \\
\text { MVAC } \times 4 \text {, then developed meningitis }\end{array}$ & no & 6 & IT MTX & 3 \\
\hline Cozzarini, 1999 [22] & III & MVAC $\times 3, P R$, surgery, MVAC $\times 2$ & no & 9 & IT MTX & 1 \\
\hline Vidal, $2000[23]$ & IV & $\begin{array}{l}\text { presented with carcinomatous meningitis, } \\
4 \text { doses IT MTX. }\end{array}$ & na & 0 & IT MTX & 1 \\
\hline Vidal, $2000[23]$ & IV & $\begin{array}{l}\text { presented with panhypopituitarism, later diagnosed } \\
\text { with meningitis }\end{array}$ & na & 1 & none & 2 \\
\hline Bruna, $2001[24]$ & IV & presented with meningitis, died of infection & na & 0 & IT MTX & 2 \\
\hline Bodi, $2004[25]$ & I & TURBT & na & 9 & none & 1.5 \\
\hline Matsushita, 2004 [26] & III & MVAC $\times 3$, surgery & yes & 16 & none & 25 \\
\hline Kim, 2005 [27] & $\mathrm{nr}$ & surgery & na & 108 & none & 1 \\
\hline Goodman, 2009 [28] & IV & taxol/carboplatin/gemcitabine/trastuzumab, surgery & yes & $\mathrm{nr}$ & IT MTX-O & 1.5 \\
\hline Butchart, 2010 [29] & II & gemcitabine-cisplatin, XRT & yes & 5 & none & 1 \\
\hline Bowen, $2010[30]$ & $\mathrm{nr}$ & surgery, gemcitabine-cisplatin $\times 4$ & yes & 31 & XRT & $\mathrm{nr}$ \\
\hline Uncu, $2010[31]$ & IV & $\begin{array}{l}\text { radiation, gemcitabine-cisplatin } \times 6 \text {, relapsed in } \\
\text { lungs in } 22 \text { months, gemcitabine-cisplatin resumed, } \\
\text { CNS disease } 2 \text { months later }\end{array}$ & yes & 36 & IT MTX/XRT & 2 \\
\hline Zada, $2010[32]$ & IV & $\mathrm{nr}$ & $\mathrm{nr}$ & $\mathrm{nr}$ & $\mathrm{nr}$ & $\mathrm{nr}$ \\
\hline $\begin{array}{l}\text { Tadepalli, } 2010 \text { [current } \\
\text { report] }\end{array}$ & IV & MVAC $\times 7$ & yes & 14 & IT MTX/XRT & 8 \\
\hline
\end{tabular}

$\mathrm{CR}=$ Complete remission; $\mathrm{Dx}=$ diagnosis; $\mathrm{IT}=$ intrathecal; $\mathrm{MTX}=$ methotrexate; $\mathrm{MVAC}=$ methotrexate, vinblastine, doxorubicin, and cisplatin; $\mathrm{na}=$ not applicable; $\mathrm{nr}=$ not reported; $\mathrm{OS}=$ overall survival; $\mathrm{PR}=$ partial remission; $\mathrm{TURBT}=$ transurethral resection of bladder tumor; $\mathrm{Tx}=$ treatment; XRT $=$ radiation 


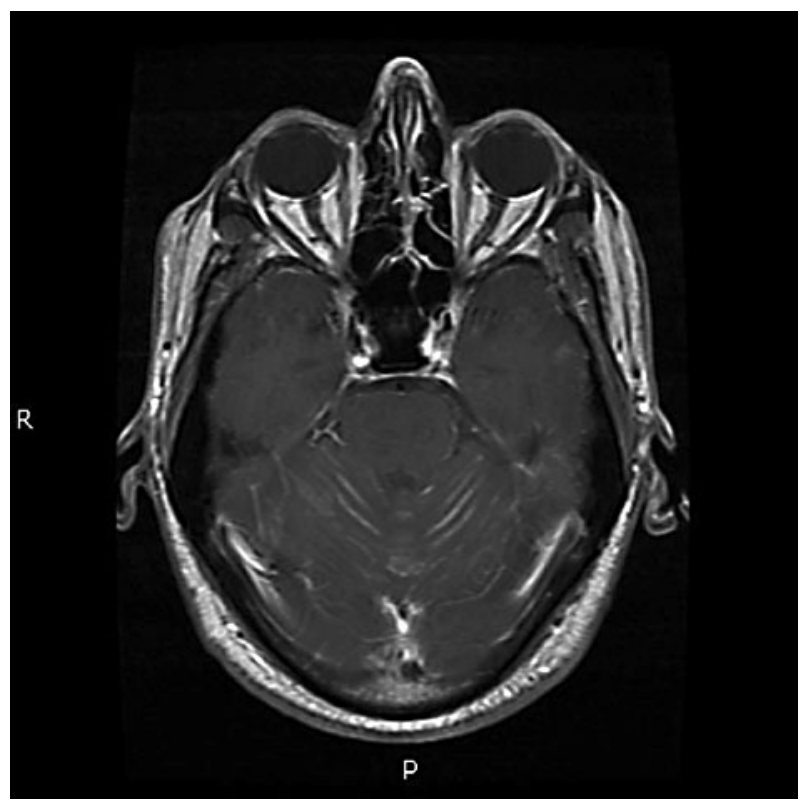

Fig. 1. $\mathrm{T}_{1}$-weighted gadolinium-enhanced MRI showing abnormal leptomeningeal enhancement patterns of the infratentorial compartment and the supratentorial basal cisterns.

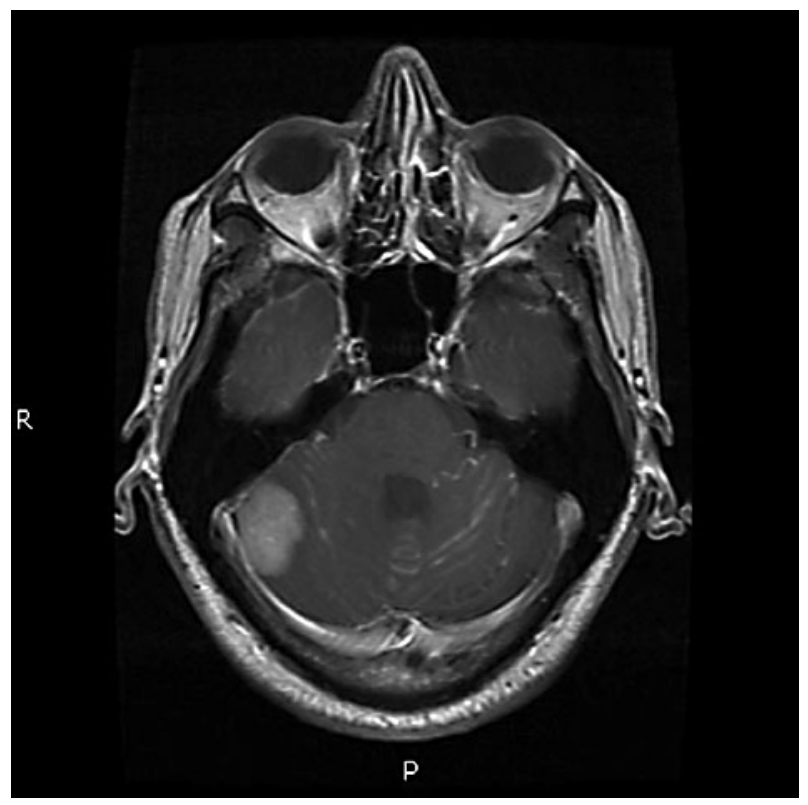

Fig. 2. $T_{1}$-weighted gadolinium-enhanced MRI showing left cerebellar encephalomalacia consistent with an old infarct of the left posterior inferior cerebellar artery. 


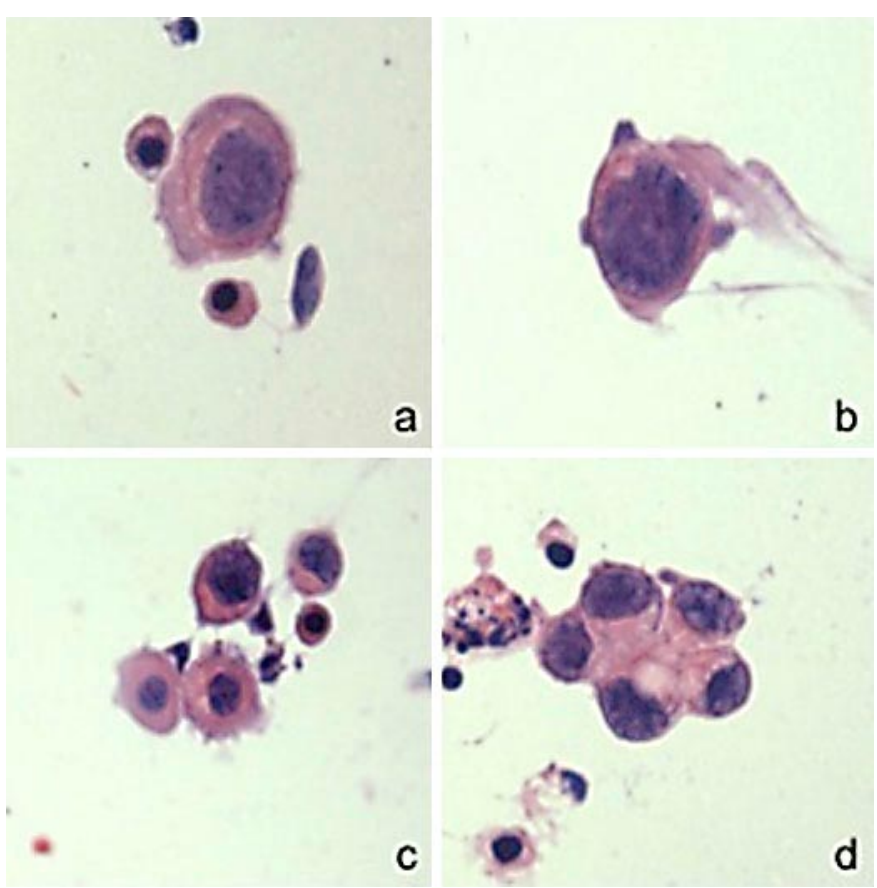

Fig. 3. Cytospin analysis of cerebrospinal fluid reveals numerous malignant cells with features consistent with metastatic high-grade TCC including large, atypical cells with increased nuclear size, prominent nucleoli, and irregular nuclear contours $(\mathbf{a}-\mathbf{c})$. Clusters of atypical cells with a papillary configuration are also identified $(\mathbf{d}) .(\mathrm{HE} \times 400)$.

\section{References}

1 Jemal A, Siegel R, Xu J, et al: Cancer statistics, 2010. CA Cancer J Clin 2010;60:277-300.

$\checkmark 2$ Anderson TS, Regine WF, Kryscio R, et al: Neurologic complications of bladder carcinoma: a review of 359 cases. Cancer 2003;97:2267-2272.

-3 DeAngelis LM: Current diagnosis and treatment of leptomeningeal metastasis. J Neurooncol 1998;38:245.

-4 Shapiro WR, Young DF, Mehta BM: Methotrexate: distribution in cerebrospinal fluid after intravenous, ventricular and lumbar injections. N Engl J Med 1975;293:161-166.

5 Glantz MJ, Van Horn A, Fisher R, et al: Route of intracerebrospinal fluid chemotherapy administration and efficacy of therapy in neoplastic meningitis. Cancer 2010;116:1947-1952.

-6 Hitchins RN, Bell DR, Woods RL, et al: A prospective randomized trial of single-agent versus combination chemotherapy in meningeal carcinomatosis. J Clin Oncol 1987;5:1655.

7 Bishop JR Jr, Moul JW, Maldonado L, et al: Transitional cell carcinomatous meningitis after M-VAC (methotrexate, vinblastine, doxorubicin, and cisplatin) chemotherapy. Urology 1990;36:373-377.

8 Matsushita M, Kawasaki Y, Okada Y: Carcinomatous meningitis from urothelial carcinoma of bladder and ureter: case report. Nippon Hinyokika Gakkai Zasshi 2004;95:817-819.

\$9 Boukriche Y, Bouccara D, Cyna-Gorse F, et al: Sudden bilateral hearing loss disclosing meningeal carcinomatosis. Rev Neurol (Paris) 2002;158:728-730.

10 Hust MH, Pfitzer P: Cerebrospinal fluid and metastasis of transitional cell carcinoma of the bladder. Acta Cytol 1980;26:217-223.

11 Mandell S, Wernz J, Morales P, et al: Carcinomatous meningitis from transitional cell carcinoma of bladder. Urology 1995;25:520-521.

12 Hussein AM, Savaraj N, Feun LG, et al: Carcinomatous meningitis from transitional cell carcinoma of the bladder: case report. J Neurooncol 1989;7:255-260. 
13 Raghavan D, Chye RWM: Treatment of carcinomatous meningitis from transitional cell carcinoma of the bladder. Br J Urology 1991;67:438-440.

14 Eng C, Cunningham D, Quade BJ, et al: Meningeal carcinomatosis from transitional cell carcinoma of the bladder. Cancer 1993;72:553-557.

-15 Steg R, Frank AR, Lefkowitz DM: Complex partial status epilepticus in a patient with dural metastases. Neurology 1993;43:2389-2392.

16 Sugimori K, Kobayashi K, Hayashi M, et al: Leptomeningeal carcinomatosis from urinary bladder adenocarcinoma: a clinicopathological case study. Neuropathology 2005;25:89-94.

17 Imamura M, Imamura S: Clinicopathologic study of leptomeningeal carcinomatosis involving the temporal bone. Ann Otol Rhinol Laryngol 1997;106:674-679.

18 Bloch JL, Nieh PT, Walzak MP: Brain metastases from transitional cell carcinoma. J Urol 1987;137:97-99.

19 Hasbini A, Himberlin C, Beguinot I, et al: La méningite carcinomateuse: une complication rare du cancer de la vessie. Rev Méd Interne 1997;18:402-406.

20 Santarossa S, Vaccher E, Balestreri L, et al: Solitary meningeal recurrence in a patient with transitional cell carcinoma of the bladder with locally bulky disease at presentation. J Neurooncol 1997;35:141-143.

21 Loizaga A, Arciniega J, Infante R, et al: Carcinomatosis meníngea en un tumor vesical. Actas Urol Esp 1999;23:873-875.

22 Cozzarini C, Reni M, Mangili F, et al: Meningeal carcinomatosis from transitional cell carcinoma of the bladder: report of two cases and review of the literature. Cancer Invest 1999;17:402-407.

23 Vidal OJ, De Paz L, Catalá J, et al: Carcinomatosis meníngea como primera manifestación del carcinoma de vejiga: a propósito de dos casos. An Med Interna 2000;17:425-428.

24 Bruna J, Rojas-Marcos I, Martínez-Yelamos S, et al: Meningeal carcinomatosis as the first manifestation of a transitional cell carcinoma of the bladder. J Neurooncol 2003;63:63-67.

-25 Bodi I, Andrews TC, Howard RS, et al: Carcinomatous meningitis from primary signet ring cell carcinoma of bladder. Histopathology 2004;44:394-396.

26 Matsushita M, Kawasaki Y, Okada Y: Carcinomatous meningitis from urothelial carcinoma of bladder and ureter: case report. Nippon Hinyokika Gakkai Zasshi 2004;95:817-819.

27 Kim P, Ashton D, Pollard JD: Isolated hypoglycorrachia: leptomeningeal carcinomatosis causing subacute confusion. J Clin Neurosci 2005;12:841-843.

-28 Goodman OB, Milowsky MI, Kaplan J, et al: Carcinomatous meningitis in a patient with Her2/neu expressing bladder cancer following trastuzumab and chemotherapy: a case report and review of the literature. J Med Case Reports 2009;3:9110.

29 Butchart C, Dahle-Smith A, Bissett D, et al: Isolated meningeal recurrence of transitional cell carcinoma of the bladder. Case Rep Oncol 2010;3:171-175.

-30 Bowen CD, Von Burton G, Bargen RC, et al: Carcinomatous meningitis secondary to transitional cell bladder cancer. South Med J 2010;103:809-812.

31 Uncu D, Arpaci F, Beyzadeoglu M, et al: Meningeal carcinomatosis: an extremely rare involvement of urinary bladder carcinoma. Tumori 2010;96:352-354.

32 Zada G, Chen T: A novel method for administering intrathecal chemotherapy in patients with leptomeningeal metastases and shunted hydrocephalus: case report. Neurosurgery 2010;67(3 Suppl Operative):onsE306onsE307, discussion onsE307.

33 Dhote R, Beuzeboc P, Thiounn N, et al: High incidence of brain metastases in patients treated with an M-VAC regimen for advanced bladder cancer. Eur Urol 1998;33:392-395.

-34 Sternberg C, Yagoda A, Scher H, et al: Preliminary results of M-VAC (methotrexate, vinblastine, doxorubicin and cisplatin) for transitional cell carcinoma of the urothelium. J Urol 1985;133:403-407.

-35 Loehrer PJ Sr, Einhorn LH, Elson PJ, et al: A randomized comparison of cisplatin alone or in combination with methotrexate, vinblastine, and doxorubicin in patients with metastatic urothelial carcinoma: a cooperative group study. J Clin Oncol 1992;10:1066-1073.

-36 von der Maase H, Hansen SW, Roberts JT, Dogliotti L, et al: Gemcitabine and cisplatin versus methotrexate, vinblastine, doxorubicin and cisplatin in advanced or metastatic bladder cancer: results of a large, randomized, multinational, multicenter, phase III study. J Clin Oncol 2000;18:3068. 